Исидора Ана Д. Стамболић

Градски музеј Суботица

isidora.ana@gmail.com doi: 10.19090/zjik.2018.39-50

UDK 821.163.42.09 Đurđević I.

прегледни рад

\title{
ЛИК МАРИЈЕ МАГДАЛЕНЕ У СПЕВУ ИГЊАТА ЂУРЪЕВИҢА
}

САЖЕТАК: Марија Магдалена је на културолошком плану један од најпознатијих библијских ликова. Недостатак чињеница о њеном животу омогућио је различите интерпретације њеног значаја и функције у јеванђеоским причама. Једно тумачење лика Марије Магдалене понудио је и Игњат Ђурђевић ускладивши га са временом у ком је живео и са потребама друштва које је настојао да поучи. У раду ћемо покушати да упоредимо представу Мандалијене покорнице са новозаветном и апокрифном представом ове личности.

Кључне речи: Нови завет, дубровачка књижевност, Марија Магдалена, жена, проститутка.

У дубровачкој књижевности можемо уочити снажан утицај средњовековне књижевности на њен тематски опсег. У њој врло често наилазимо на идејну концепцију која је била карактеристична за средњовековно поимање човека, Бога и света. Многа дела су бивала само прилагођена дубровачком говору, а изворно су потицала из средњовековне књижевности, попут средњовековног романа Александриде, али и приповестима о Розани, Јосафату, Авраму, Сузани, Марији Египћанки итд. У науци су прилично позната два дубровачка средњовековна зборника. Први под називом Дубровачки зборник (1520) и други под називом Дубровачке легенде. Дубровачки зборник се састоји из три дела. Првог који је био дидактичкоапокрифног карактера, другог који чине легенде и састави преведени са италијанског језика и трећег који представља календар за врачање и тумач снова пророка Данијела. Нама је, због наше теме пак, много значајнији други поменути зборник - Дубровачке легенде. Овај зборник представља пре свега зборник хагиографске прозе која је морала имати утицај на поимање одређених ликова из религиозне литературе. Он садржи апокрифно Усnење Богородице, али и Живот блажене Розане, Живот Свете Еуфрозине, Живот

\footnotetext{
${ }^{1}$ Рад је настао под менторством др Невене Варнице у оквиру курса друге године докторских студија под називом „Жене у књижевности и култури старог Дубровника”.
} 
Свете Пелагије и Живот Свете Марије Египатске (Бојовић 2014: 16). ${ }^{2}$ Видна је множина хагиографских дела у зборнику, повезаних са хришћанским светитељкама које су доживеле преобраћење из греха у хришћанство. На сличну концепцију наилазимо у житијима попут Житије Аврамија затвореника и братанице му Марије, Житије преподобне Пелагије, Житије преподобне Тисе итд. Могућ је утицај овакве хагиолошке традиције на представу Марије Магдалене Игњата Ђурђевића у његовом спеву Уздаси Мандалијене покорнище.

Од времена појављивања житија, преко његових најранијих латинских превода водио је пут највећег маријинског утицаја од Истока ка западној литератури. По Г. Г. Меерсеману, Акатист Богородици, Легенда о Теофилу и Житије Mapuje Египћанке употпуњавају овај низ Богородичиних атрибута који ће бити главни ослонац потоње мариолошке књижевности (Шпадијер 1992: 186).

О личности Марије Магдалене у дубровачкој књижевности су писала два песника. Џиво Бунић написао је спев о Мандалијени покорници невеликог уметничког домета. Предпоставља се да је настао, пре свега, као израз љубави и бриге према сестри која је у монаштву узела име Мандалијена (Павловић 1971: 373). Друго дело је, већ поменути, религиозно-рефлексивни спев Игњата Ђурђевића Уздаси Мандалијене покорнице $е^{3}$ који је уметнички високо вреднован и представља истакнути пример те врсте песништва. Познато је да су Игњата Ђурђевића инспирисале библијско-религиозне теме, те је писао религиозне песме о Христу, светој Катарини, светом Амброзу и Августину и преводио псалме Давидове на словенски језик (Бојовић 2014: 424-426). Међутим, стварајући спев о покајништву новозаветне личности Марије Магдалене он се, уз религиозне теме окајања, исповести и посвећивања, бави и дидактичким аспектом свог дела које је требало да поучи дубровачке „диклице”, како је то сам нагласио у предговору спева. Спев са темом

\footnotetext{
${ }^{2}$ Ми смо издвојили она хагиографска дела која би могла да имају везе са нашом темом, али уз њих су се у зборнику Дубровачких легенди налазиле и молитве против грома и муње Светом Јосипу, као и Живот Светог Јосафата и Барлаама.

${ }^{3}$ Овај религиозно-рефлексивни спев Игњат Ђурђевић је испевао 1714. године (податак који знамо на основу преписке из 1718. Ђуре Матијашевића и Иве Наталића Аветина који су се бавили темом преслободних стихова у самом спеву). Објавио га је 1728. године у Венецији са двадесетак других духовних песама (Бојовић 2014: 424).
} 
покајања налазио се у центру барокне моралне дидактике те образложење Игњата Ђурђевића у Предговору ни мало не изненађује (Бојовић 2014: 424).

Да бисмо се бавили ликом Марије Магдалене и разумели идеје које њен лик сабира и представља у поменутом спеву Игњата Ђурђевића, морамо првенствено поћи од библијског предлошка и уочити одређене специфичности. Наиме, од средњег века у Западној цркви Марија Магдалена се описује као жена која је била порочна и која је имала грешну прошлост, а која се обратила вери слушајући Христова учења. За њу се везују врло упечатљиве и значајне приче о прању Христових ногу и првом виђењу Христа након васкрсења. Међутим, савремени проучаваоци новозаветног текста наглашавају да су се у предању о Марији Магдалени сабрале и приче које нису директно повезане са њом, већ са другим женама које се јављају у јеванђељима. ${ }^{4}$ Злата Бојовић наглашава да се у лику Марије Магдалене заправо синтетисало три личности (Бојовић 2014: 425), највероватније мислећи на Марију из Витаније, анонимну грешницу и саму Марију Магдалену. Спајањем три поменуте личности из јеванђеоских текстова добијена је прича о исцељеној проститутки, која се одрекла пређашњег живота и пошла за проповедањем Исуса Христа.

Марију Магдалену помињу сви јеванђелисти (Лк 24: 10; 8: 2; Јн: 19: 25; 20: 11-18; Мк 16: 40; 16: 19; Мт 27: 56. 61; 28: 1), што нам говори о њеном значају у ранохришћенској заједници. ${ }^{5}$ Осим тога, она је једина жена у јеванђељима која није одређена односом према мушкарцу тј. она није ничија сестра, мајка или жена, за разлику од свих осталих женских актера у јеванђеоским причама. Та чињеница указује на индивидуалност личности Марије Магдалене као и на њен особит значај. У Јеванђељу по Луки (Лк 8: 29) Марија Магдалена се помиње као жена из које је Христос „истерао” седам злих духова. На сличну информацију наилазимо у Јеванђељу по Марку који, када идентификује жене које су виделе Исуса Христа након васкрсења, за

\footnotetext{
${ }^{4}$ Види: Thompson, R. Mary (2006). Mary of Magdala: What the Da Vinci Code Misses. Paulist Press; Chilton, Bruce (2005). Mary og Magdala: Biography. Crown Publishing Group

5 У Новом завету срећемо многе жене у разним црквеним улогама: мисији, богослужењу и вођењу заједнице. Међу њима су најпознатије Приска, која је са супругом Акилом помагала апостолу Павлу (1 Кор 16: 19; Рим 16: 3; Дап 18: 18-19), Фива, служитељка у цркви у Коринту (Рим 16), Јунија, мисионарка (Рим 16:17), Нимфа итд. (Види: Драгутиновић 2015: 205-209).
} 
Марију Магдалену наглашава да је из ње истерано седам демона (Мк 16: 9). Јеванђелиста Јован и Матеј не помињу истеривање злих духова, већ Марију Магдалену спомињу у причама о распињању Исуса Христа на крст (Јн 19: 25) и у причи о васкрсењу (Мт 28: 11-18). Међутим, ни у једном јеванђељу не постоји конкретна информација да је Марија Магдалена била проститутка покајница. Стога је занимљиво да је Марија Магдалена у Западној цркви врло често описивана као окајана грешница, како ће то чинити и Игњат Ђурђевић у складу са општим ставом цркве. Близина одељка о анонимној грешници која је опрала Христове ноге из посуде од алабастера и одељка у коме се помиње Марија Магдалена у Матејевом јеванђељу могла је да допринесе конфузији. Уз то, велики број жена које се помињу у јеванђељу се зову Марија, стога није чудно што се Марија Магдалена често изједначавала са Маријом из Витаније, сестром Марте и Лазара, која је имала „раскалашну” прошлост. Управо исти поступак ће начинити и Игњат Ђурђевић у другом поглављу свог спева, где ће у исповести Марије Магдалене навести имена њене сестре и брата - Марта и Лазар. ,/Брат о себи Лазар сташе,/ Марта с мало веће љета/ ни смијаше ни могаше/ по годиштијех дат ми свјета;/ беше себи младост моја/ и свјетница и госпоја/" (Ђурђевић 1997: 19).

Григорије Велики је још 591. године тврдио да је жена грешница из Лукиног јеванђеља, Марија из Витаније о којој пише Јован, и Маркова Марија из које је изгнано седам демона - иста жена (Види: Драгутиновић 2015: 144). Папа Гргур Велики је у Риму 14. септембра 1591. године у својој омилији званично изједначио Марију Магдалену, неименовану грешницу и Марију из Витаније, те је сасвим разумљиво што Игњат Ђурђевић, као свештено лице Римокатоличке цркве, у свом опису Марије Магдалене сједињава карактеристике ове три јеванђелске личности. Уз то, описи жене у религиозној литератури се најчешће крећу од грешнице до грешнице покајнице, док је као идеал жене најчешће представљена Богородица и светитељке које теже сличном савршенству (девственост, посвећеност Богу, молитвеност итд.).

Лик Марије Магдалене у спеву Игњата Ђурђевића, пак, производ је неколико традиција: римокатоличког читања, ${ }^{6}$ библијске традиције, апокрифне традиције и барокног поимања жене. У поменутој библијској новозаветној

6 Наглашавамо да је описивање Марије Магдалене као покајане грешнице читање Западне цркве. У Источној хришћанској заједници није поклањала велика пажња овом лику, нити је он тумачен као у Западној. 
традицији, дакле, Марија Магдалена је пре свега била следбеница Исуса Христа и потоњи његов апостол, која је приступила хришћанском учењу исцеливши се од злих духова ${ }^{7}$ (,демона”). Средњовековна западно-црквена тумачења те традиције су Марију Магдалену представила као грешницу, развратницу и жену ниског морала која је пошла за Христом, док је у апокрифној традицији ситуација посве другачија. Наиме, у апокрифном Јеванђељу по Марији наводи се њен дијалог са Исусом Христом у коме је изложено дуалистичко учење о злој материји и доброј души, а потом разговор Марије Магдалене и апостола Петра и Андрије. ${ }^{8}$ У неповерењу апостола према жени, Леви наглашава да је Исус Христос Марију Магдалену „љубио” више но друге своје апостоле. Неповерење и сукоб апостола Петра и Марије Магдалене помиње се и у апокрифном Еванђељу по Томи и Еванђељу по Египћанима (Парот 1990: 488).

Марија тад заплака и рече Петру: Петре, брате мој, ито мислиш тиме? Зар мислиш да сам све то у свом сриу замислила, или да лажем о Спаситељу? Леви се обрати Петру, и рече, Петре, увијек си био нагле нарави. Видим да се према жени односиш као према непријатељима својим. Ако ју је Спаситељ учинио достојном, тко си ти да је одбаиујеш? Спаситељ је засигурно добро познаје, и зато ју је љубио више него нас. (БГ 7М 1-19,5)

Можемо закључити да се апокрифна и библијска традиција не разликују у потпуности, већ да се разликују приступи и тумачења поменутих текстова. Наиме, ни канонски новозаветни текст ни апокрифно јеванђеље не садржи опис Марије Магдалене као грешнице која се покајала, иако се у

\footnotetext{
7 Менталне болести су се често у средњовековној традицији изједначавале са запоседнутошћу ђаволом.

${ }^{8}$ Постојећи текст Еванђеља по Марији се дели на два дела. Први део (7, 1-9, 24) представља дијалог између васкрслог Христа и ученика, при чему се разматра однос материје и греха. Након дијалога Христос напушта ученике, који остају у недоумици, а Марија Магдалена их теши и поучава. Други део текста (10, 1-23; 15, 1-19, 20) садржи посебно откровење које је Спаситељ дао Марији Магдалени и опис сукоба апостола Петра и Марије. Тај сукоб представља одраз тензија које су биле присутне у хришћанству другог века. Петар и Андрија представљају ортодоксна стајалишта својим порицањем значаја езотеричног откровења и одбацивањем жене као учитеља. Еванђеље по Марији се супротставља таквом становишту. Сам текст припада жанру гностичких дијалога, али је често одређен и као откровење. Научници сматрају да су два описана дела текста засебно настала и да су тек касније спојена у целину (Кинг 1990: 488).
} 
апокрифном тексту осећа анимозитет према женском полу, што може бити и производ конзервативног погледа на положај и функцију жене у друштву. Уколико узмемо у обзир да се у Старом завету жена од описа Еве па надаље, врло ретко представља као носилац врлине, у Новом завету жене су врло значајни актери. Пре свега, жене су те које су остале последње крај крста, када су се сви ученици разбежали (Јн 19: 25) и женама се Исус Христос први јавио након васкрсења, а међу тим женама, увек је посебно истакнут лик Марије Магдалене. На тај начин видимо промену библијског текста у односу према женама и њиховој функцији која је ишла од осуђивања старозаветне Еве, која је човечанство „сурвала” у пропаст, до поимања Богородице, која је човечанству подарила спаситеља. Ипак, средњовековна традиција је због поимања греха и грешности жене, као и конзервативне перцепције женског тела, била ближа старозаветном поимању жене као „грешног бића” које не само што је грешно, већ наводи и друге на грех. Тако је жена често поимана као слуга или сарадник ђавола. Уколико се радило о представи светитељке, увек се инсистирало на раскидима са телесним животом, на одржавању завета девствености и на генералном изнуривању тела до мере да женско тело почиње да личи на мушко. Можда је најбољи пример за такву представу животопис Марије Египћанке - блуднице, која је окајавала своје грехе у пустињи, до краја живота и чије је подвизавање довело до потпуне непрепознатљивости њеног лика, или животопис Свете Еуфрозине која се због лепоте осамила, како не би наводила друге на грех. ${ }^{9}$

У барокној књижевности наилазимо на повратак средњовековној традицији, на повратак мистицизму и догматизму, као и религиозноморалистичкој дидактици која се претежно концентрисала на тему покајања (Бојовић 2014: 256). Стога је религиозно-рефлексивни спев Уздаси Мандалијене покорнище Игњата Ђурђевића сасвим у маниру барока. Ипак, треба нагласити да је опис спољашњости Мандалијениног лика сличнији ренесансном опису жене као златокосе белог лица (Еко 2004: 156- 175), ${ }^{10}$ те би

\footnotetext{
9 Оба животописа била су позната дубровачким писцима, јер су се, како смо већ наводили, налазила у зборницима средњовековних дела (Дубровачке легенде).

10 „/Дразијем водам прво умивам/ снијег наравни пути биле;/ повраћам се, промењивам/ иза вода воде миле,/ али у тему није ми дости/ задовољно сјат светлости,// нег из суда мириснога/ присађивам хитром власи/ још на лијере лица мога/ од снежне лијер помасти/ и над русам мо’им истиним/ силни тратор ницат чиним.// Пак на праме руку уздижем/ и њих мучећ себе трудим/ правим, дијелим, скубем,
} 
нас Мандалијена пре могла подсетити на Петраркину Лауру него ли на „црнчицу” дубровачких песника. Посматрајући пак целокупан опис и израз Мандалијениног карактера, можемо закључити да је он приказан у чисто барокном маниру. Уколико изоставимо описе пејзажа, који нису ретки у поменутом делу, поуке о Богу и вери, и ако се концентришемо искључиво на лик Мандалијене, увидећемо да ја она носилац готово свих барокних идеја.

Мисао о смрти и пролазности, која је у средњовековној и барокној традицији уздигнута на пиједестал, представљена је и кроз лик Мандалијене. У Уздисању првом, где је описан њен боравак у самотној пећини, Мандалијена инсистира на сталној мисли о смрти која проистиче из сагрешења. Ипак, најјасније изражен мотив пролазности представљен је у Уздисағу другом које има функцију исповести и које нам пружа увид у промену Мандалијене. ${ }^{11}$ Игњат Ђурђевић даје опис пређашњег, раскошног живота и лепоте Мандалијене, настојећи не да је прикаже реално већ што сродније и ближе „диклицама” свог доба. Стога он Мандалијену представља крај прозора и огледала, описује како се стално украшава и дружи са погрешним друштвом, како ступа у недозвољене контакте са мушким полом, како прима песме које joj се певају под прозором. Сви поменути описи никако не би могли да буду везани за реалну личност жене из првог века, али су свакако били блиски девојкама дубровачког краја из XVII и XVIII века. Игњат Ђурђевић не настоји само да прикаже пропаст лепоте у греху и њено приближавање смрти, већ нуди и алтернативну слику срамежљиве девојке, коју Мандалијена након свог искуства заступа. На тај начин су идеје о пролазности лепоте и приближавању смрти доведене у функцију хришћанске моралне дидактике. Грех таштине, који такође представља једну од тема барокног стваралаштва, испољен је кроз Мандалијенину неосетљивост на реакцију и упозоравање друштва, кроз заокупљеност самом собом. „/Ташта у мени слас отрова/ све што 'е твое, краљу од неби,/ што ми обилнос тва дарова,/ све обратих супроћ теби,/ и нехрана нада свима,/ увриједих те тво’им дарима/" (Ђурђевић 1977: 24)

стрижем/ спуштам, плетем, вежем, трудим,/ докле учине у два дијела/ златну дугу сунцу од чела/" (Ђурђевић 1977: 28)

11 ,/Ја те изгубих у несцини,/ а сад познам цијену твоју,/ негда уресу мој једини,/ сад изгубљен мој покоју!/ у невријеме јаох познани/ цвијете од раја, сраме избрани/" (Ђурђевић 1977: 22) 
Читаво Мандалијенино оплакивање саме себе пре покајања, које је било очигледно осуђивано од савременика због директног описа греха и слободних стихова, имало је функцију да укаже на погрешке које девојка може да учини. Сликајући анимозитет између телесног и духовног Игњат Ђурђевић нам је у Уздисању трећем дао савршен портрет даме свог времена који описује лице, косу, уши, грло, руке и бедра, али ништа ниже паса. Телесност и посвећивање пажње телесном су приказани као грех, а мучење тела као део покајања. Тако се још у Уздисағу првом Мандалијена кажњава бичем и изгладњивањем, лишава се угађању телу тј. злу.

Ипак, сензуалност није у потпуности уклоњена из Мандалијенине личности. Она је присутна, али није изражавана према супротном полу, већ према Богу. Познато је да је у Дубровнику важио обичај да се ћерке које немају довољан мираз „удају за Христа” тј. да одлазе у самостане где бивају замонашене. Дешавања у Римокатоличкој цркви која су уследила након Тридентског сабора и прописивања строгих прописа од стране Пија V (1571) и потврђених од стране Гргура XIII 1572. године довела су до значајне промене статуса монахиња и њиховог живота (Вилари 2004: 237-238). Реформацијом женских монашких редова и прописивањем строге клаузуре дошло је до повратка строжим и грубљим условима живота у манастиру у XVII веку у читавој католичкој Европи. Све то је могло утицати на грађење лика Мандалијене код Игњата Ђурђевића. Како смо већ навели, световни лик „распусне грешнице” грађен је према савременим типовима женских ликова Игњата Ђурђевића, те водећи се тиме, можемо претпоставити и да је преображен лик Мандалијене покајнице грађен према редовницама или појединим светитељкама-оснивачима женских монашких редова попут Терезе Авилске, Анђеле Меричи, Марије Магдалене де Паци, Веронике Ђулијани, Марије Магдалене Мартиненго итд. (Вилари 2004: 238-242).

Света Тереза Авилска хронолошки припада XVI веку, али је њен утицај на духовност у женским манастирима у XVII веку (и не само на духовност) такав да, ко жели да у крупним цртама пређе разуђени пут барокне мистике, не може никако да заобиђе унутрашње искуство пренесено кроз њена дела која су имала огроман успех” (Вилари 2004: 273).

Дакле, пример свете Терезе Авилске и других могао је дати скицу за формирање Ђурђевићеве Мандалијене која се попут поменуте светитељке упуштала у мистичне заносе, мучећи своје тело и сензуално се спајајући са 
Богом. Мандалијена „покорница” се сензуално односи према Богу кроз молитву која је пуна љубави која подсећа на ону међу љубавницима, стога је читаво седмо поглавље Ђурђевићевог спева посвећено теми љубави према Богу. Седмо поглавље Ђурђевић користи да изрази контраст између љубави према пролазним, материјалним стварима и вечним, непропадљивим тј. према Богу. Марија Магдалена и њена љубав ка Христу је очигледно била веома привлачна за жене у хришћанској заједници, самим тим што врло често међу редовницама наилазимо на име Мандалијена или Марија Магдалена. Монахиње су се угледале на њен пут јер је представљала симбол женске привржености Богу, а не отпадништва, какво је симболисала Ева. Иако је Богородица представљала врхунски црквени идеал за жене, са њом се није било лако поистоветити, док је ситуација сасвим другачија са Маријом из Магдале. Грехе које је Марија Магдалена наводно починила приближавали су је обичном човеку. Са њом се могло идентификовати и поистоветити у покајним молитвама пред Богом. Марија Магдалена ди Бароко (1687-1737) је стога, пишући своју (необјављену) Аутобиографију, себе и свој животни пут изједначавала са Мандалијениним (Вилари 2004: 277). Она је у потпуности изражавала модел сензуалне страсне љубави према Богу:

Бог је милост, а милост је Бог. Када се душа преобрати у Бога, сва гори од милости. Дакле ова љубав је нежна, љупка, мирна... Жар који понекад осетим је неподношљив... Када, дакле, осетим да тако горим, шћућурим се у себе саму и препустим се љубави да ме она сву потроши, и потпуно сам мирна, не помичем се и једва се усуђујем да удахнем. Да се не би дало повода оном жестоком кључању, унутра се ништа не помера, пушта се да љубав чини своје. На тај начин умирује се чулна љубав, а све се више разбуктава суштинска (Према: Вилари 2004: 277-78).

На стихове са истом идејом наилазимо код Игњата Ђурђевића:

/Ми смо љубав, и у човика/ што је душа, љубав то је;/ душа с хтијенијем није разлика, хтијеније и љубав знај да исто је; дакле осудит мож праведно/ душа и љубав да 'е све једно/... Ах љубим те твом у крилу/ ето издишем, ax jaox боже!/ ето плама твога силу/ мој поднијети дух не може;/ ax сладости, ах љубави,/ ах јаох гинем, дух ме остави! $/^{12}$

\footnotetext{
${ }^{12} \mathrm{http}: / /$ www.rastko.rs/rastko/delo/10061
} 
Све то говори у прилог намери Игњата Ђурђевића да намени дело девојкама свог друштва, као и да је из великог поштовања личности Марије Магдалене происходило литерарно приближавање савременом и актуелном. Припаднице монашких редова су се инспирисале и угледале на личност Марије Магдалене, а Марија Магдалена је у барокним делима попримала одлике тадашњих монашких предводница.

Блискост Марије Магдалене и Исуса Христа у Ђурђевићевим стиховима би се могла тумачити и као утицај апокрифне традиције која је истицала Христову посебну наклоност ка Марији Магдалени, коју су према наведеним цитатима гностичких јеванђеља приметили чак и апостоли. Тако је Марија Магдалена, слободнијим тумачењима апокрифних текстова претворена у део контраверзе која се везивала за личност Исуса Христа. Ипак, треба нагласити да Игњат Ђурђевић није повезивао Христа и Мандалијену телесном, већ религиозно-духовном љубављу. У четвртом поглављу он је назива невестом Христовом, али у контексту њеног одрицања од световног, попут оног које су вршиле млађе сестре без мираза у манастирима Дубровника и шире.

Осим тога, Мандалијена демонстрира и мистицизам који је био својствен барокном стваралаштву. Наиме, целокупно осмо поглавље у коме она ступа у контакт са оностраним пре своје смрти, пример је барокног религиозног заноса и наклоности ка мистичком виђењу Бога. Ипак, треба напоменути да се идентични поступци могу наћи у апокрифној литератури у причи о смрти Еноховој, Варуховој, Авраамовој итд. Све поменуте старозаветне личности добијају могућност од Бога да виде „онај” свет пре смрти. На тај начин Мандалијена Игњата Ђурђевића задобија значајни религиозни статус. Како смо већ поменули, многе светитељке Римокатоличке цркве имале су мистичне визије и комуницирале су са оностраним, те Игњат Ђурђевић оваквим поступком Мандалијену повезује и са канонским виђењем римокатоличких светих жена.

Игњат Ђурђевић је представио животни пут Мандалијене „покорнице” од почетка до краја, осврнувши се на све значајне тренутке, који су јој били приписивани у црквеним веровањима. Она је лик жене која је згрешила, али се покајала, која се узвисила у својим молитвама и доживела мистична пројављења. Описујући је, настојао је да прикаже њену љубав ка Исусу Христу, њено дивљење Богородици, њено одрицање од материјалног и 
телесног у функцији давања примера својим савременицама. На тај начин Мандалијена у спеву Игњата Ђурђевића уз прослављену светитељку ипак истовремено представља и пожељни, очекивани идеални тип покајнице, пожељне у конзервативном религиозном друштву, које настоји да у свакој жени пронађе и искорени Еву и прослави недостижни идеал Богородице.

\section{ЛИТЕРАТУРА}

Бојовић, Злата. 1997. Игъат Ђурђевић. Београд: Просвета.

Бојовић, Злата. 2014. Историја дубровачке књижевности. Београд: Српска књижевна задруга.

Вилари, Розарио. 2004. Ликови Барока. Београд: Клио.

Драгутиновић, Предраг. 2015. Који чита да разуме. Београд: Хришћански културни центар „Др Радован Биговић”.

Еко, Умерто. 2004. Историја лепоте. Београд: Плато.

Комбол, Миховил. 1945. „Уздаси Мандалијене покорнице”. Спремност IV, 153.

Макманерс, Џон. 2004. Оксфордска историја хришћанства. Београд: Клио.

Матановић, Јулијана. 1992. „Примарна и секундарна генеричка обележја у Ђурђевићевим Уздасима Мандалијене Покорнице". Барок из сувремености гледан. Осијек.

Павић, Милорад. 1970. Историја сепске књижевности барокног доба. Београд: Нолит.

Павловић, Драгољуб. 1971. Старија југословенска књижевност. Београд: Научна књига.

Томановић, Васо. 1928. „Света Марија Магдалена у талијанској и дубровачкој књижевности". Записи II, 31-41.

Шпадијер, Ирена. 1992. „Житије Марије Египћанке у рановизантијском књижевном контексту". Кюижевна историја XXIV, 87. Београд: Институт за књижевност и уметност. 
Isidora Ana, D. Stambolić

\section{CHARACTER OF MARY MAGDALENE IN IGNJAT ĐURĐEVIĆ'S EPIC}

\section{Summary}

Mary Magdalene is, on the cultural plain, one of the most famous biblical characters. The lack of facts about her life made possible the different interpretations of her significance and function in gospel stories. One interpretation of the character of Mary Magdalene was also offered by Ignjat Đurđević, who harmonized it with the time in which he lived and the needs of the society he was trying to teach. In this paper we will try to compare the concept of Mandaline The Penitent with the depiction of this character in the New Testament and the Apocrypha.

Keywords: New Testament, Dubrovnik Literature, Mary Magdalene, woman, prostitute. 